\title{
Unusual Prenylated Stilbene Derivatives with PTP1B Inhibitory Activity from Artocarpus styracifolius
}

\author{
Authors \\ Wenyan Li ${ }^{1}$, Zhongji Pu ${ }^{2}$, Wenfang $\mathrm{Yi}^{1}$, Qinge Ma ${ }^{1}$, Qinhua Lin ${ }^{3}$, Guoyue Zhong ${ }^{1}$, Pengcheng Yao ${ }^{1}$, Gang Ren ${ }^{1}$ \\ Affiliations \\ 1 Research Center of Natural Resources of Chinese Medicinal \\ Materials and Ethnic Medicine, Jiangxi University of Tradi- \\ tional Chinese Medicine, Nanchang, China \\ 2 School of Life Science and Biotechnology, Dalian University \\ of Technology, Dalian, China \\ 3 School of Pharmacy, Gannan Health Vocational College, \\ Ganzhou, China \\ Key words \\ Artocarpus styracifolius, Moraceae, prenylated stilbene, \\ diabetes, PTP1B inhibitory activity, molecular docking \\ received May 29, 2019 \\ revised August 28, 2019 \\ accepted September 12, 2019 \\ Bibliography \\ DOI https://doi.org/10.1055/a-1013-1417 \\ Published online October 11, 2019 | Planta Med 2019; 85: \\ 1263-1274 @ Georg Thieme Verlag KG Stuttgart · New York | \\ ISSN 0032-0943 \\ Correspondence \\ Prof. Dr. Gang Ren \\ Research Center of Natural Resources of Chinese Medicinal \\ Materials and Ethnic Medicine, Jiangxi University of Traditional \\ Chinese Medicine \\ No. 1688, Meiling Road, Wanli District, \\ Nanchang 330004, China \\ $\circledast$ \\ Supporting information available online at \\ http://www.thieme-connect.de/products

\section{ABSTRACT} \\ In an effort to identify agents from natural products that in- \\ hibit protein tyrosine phosphatase 1B (PTP1B), 5 new preny- \\ lated stilbenes, $( \pm)$-styrastilbene $A(1)$, styrastilbene $B(2)$, \\ and $( \pm)$-styrastilbenes $C-E(3,4$, and 7$)$, along with 4 known \\ structurally related compounds $(5,6,8$, and 9$)$, were isolated \\ from the roots of Artocarpus styracifolius. Their structures \\ were elucidated by spectroscopic methods, including 1D and \\ 2D nuclear magnetic resonance (NMR), high-resolution elec- \\ trospray ionization mass spectrometry (HRESIMS), ultraviolet \\ (UV), and infrared (IR). Based on these isolates, a new plausi- \\ ble biosynthetic pathway for the unusual stilbene derivatives \\ 3-8 with a tetracyclic ring system is proposed. Among these \\ compounds, 1-3, 8, and 9 displayed significant PTP1B inhib- \\ itory effects with $\mathrm{IC}_{50}$ values ranging from 2.40 (95\% confi- \\ dence interval $[\mathrm{Cl}]: 2.21-2.59)$ to 8.80 (95\% Cl: 8.28-9.32) \\ $\mu \mathrm{M}$. Moreover, kinetic analysis and molecular docking simula- \\ tions were performed to provide insight into the inhibition \\ type as well as the interaction and binding mode of these ac- \\ tive isolates with PTP1B. Our results revealed mixed-type \\ PTP1B inhibition for all compounds tested. Docking simula- \\ tions of these stilbene derivatives showed negative binding \\ energies and close proximity to residues at the allosteric and \\ catalytic sites of PTP1B. These findings suggest that these \\ compounds may have a potential to be further developed as \\ agents for the management of type 2 diabetes mellitus.
}

Phone: + 8679187119067 , Fax: + 8679187119067

20091005@jxutcm.edu.cn

\section{Introduction}

During the last few decades, the incidence of diabetes globally has increased at an alarming rate due to changes of lifestyle and dietary structure, as well as the aging of the population. Type 2 diabetes mellitus (T2DM) is the major diabetes type, which is estimated to account for up to $90 \%$ of all cases $[1,2]$. T2DM is a chronic metabolic disease characterized by hyperglycemia and $\beta$ cell dysfunction and primarily caused by insulin resistance. Insulin resistance is closely associated with the interruption of metabolic insulin signal transduction, which occurs through dephosphorylation of the insulin receptor. Several protein tyrosin phosphatases, such as receptor protein tyrosine phosphatase, leukocyte antigenrelated tyrosine phosphatase, and protein tyrosine phosphatase 1B (PTP1B), have been implicated in dephosphorylation of the insulin receptor [3]. Among these, PTP1B has been identified as a key player that negatively regulates insulin signaling by dephosphorylating insulin receptor, as well as downstream signaling insulin receptor substrate proteins $[4,5]$. Therefore, PTP1B inhibition represents a highly promising approach to control the insulin signaling pathway. Mounting evidence suggests that PTP1B inhibitors can improve and/or prolong the action of insulin and they are considered to be candidate agents for the treatment of T2DM [6-8]. 


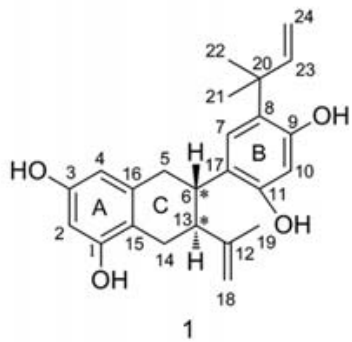<smiles>[R]c1cc2c(cc1O)OC(C)(C)[C@@H]1Cc3c(O)cc(O)cc3C([R7])[C@@]21C</smiles>

$4 \mathrm{R}_{1}=\xi \stackrel{-1}{-1} \mathrm{R}_{2}=\xi t$

$5 \mathrm{R}_{1}=\mathrm{H}, \mathrm{R}_{2}=\xi+$

$6 \mathrm{R}_{1}=\mathrm{OH}, \mathrm{R}_{2}=\xi+$<smiles>C=CC(C)(C)c1cc(/C=C/c2cc(O)cc(O)c2C=CC(C)C)c(O)cc1O</smiles><smiles>C=CC(C)(C)c1cc2c(cc1O)OC(C)(C)[C@H]1Cc3c(O)cc(O)cc3C(=O)[C@@H]21</smiles>

7

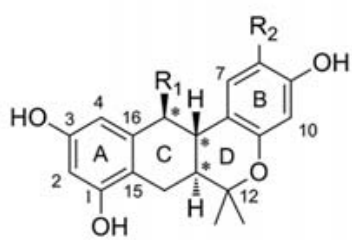

$3 \mathrm{R}_{1}=\xi t_{-}, \mathrm{R}_{2}=\mathrm{H}$

$8 \mathrm{R}_{1}=\mathrm{H}, \mathrm{R}_{2}=\xi+$<smiles>Oc1cc(O)cc(C=Cc2ccc(O)cc2O)c1</smiles>

9

- Fig. 1 Structures of compounds 1-9.

Artocarpus plants (Moraceae) are well known as an abundant source of secondary metabolites, consisting predominantly of prenylated phenolic compounds, including flavonoids, stilbenes, and 2-arylbenzofurans [9]. Recently, some stilbene derivatives from Artocarpus nanchuanensis S. S. Chang have been found to display interesting PTP1B inhibitory activity [10]. This prompted us to search for PTP1B inhibitors from Artocarpus plants. Artocarpus styracifolius Pierre, a species distributed in the North of the Indochinese peninsula and southern China, is an evergreen arbor tree morphologically characterized by an upright trunk and yellow-orange fruit. In China, A. styracifolius is widely cultivated for its edible fruit that is used locally to make jam and wine [11]. The roots of this plant are documented to have various therapeutic effects and are used as a folk medicine to treat rheumatism, psoatic strain, rheumatic heart disease, diabetes, and hemiplegic paralysis [12]. Like other members of the genus Artocarpus, A. styracifolius was previously reported to contain prenylated flavonoids, stilbenes, and 2-arylbenzofurans with various bioactivities, such as anti-plasmodial, anti-trypanosomal, anti-respiratory burst, and cathepsin K inhibitory effects [13-16]. In a search for PTP1B inhibitors from natural products, a chloroform-soluble extract from the roots of $A$. styracifolius was found to inhibit PTP1B activity (90\% inhibition at a concentration of $50 \mu \mathrm{g} / \mathrm{mL}$ ). In the present study, a phytochemical investigation of this active extract was performed, which led to the isolation of 5 new prenylated stilbenes (1-4 and 7) along with 4 known structurally related compounds $(5,6,8$, and 9). All isolates were examined for their PTP1B inhibitory activities, and the inhibitory modes of the active compounds were elucidated by inhibition kinetic analyses and molecular docking simulations. Furthermore, based on the new compounds obtained in the present study, a more plausible biosynthetic pathway than the one previously proposed is suggested for the stilbene derivatives 3-8 with an unusual tetracyclic ring skeleton.

\section{Results and Discussion}

The air-dried roots of $A$. styracifolius were exhaustively extracted with $95 \% \mathrm{EtOH}$. The $\mathrm{CHCl}_{3}$-soluble portion of the hydroalcoholic extract was separated by column chromatography (CC) on HP-20 macroporous resin, $\mathrm{MCl}$ CHP-20P resin, Sephadex $\mathrm{LH}-20$, and ODS, followed by preparative HPLC (PHPLC) to afford 5 new compounds (1-4 and 7) and 4 known ones, hypargystilbene $A(5)$ [17], hypargystilbene $D(6)$ [10], hypargystilbene $B(8)$ [10], and transoxyresveratrol (9) [18] ( Fig. 1). To the best of our knowledge, this is the first report of the occurrences of compounds 5,6 , and 8 in A. styracifolius.

Compound 1, a yellow amorphous powder, was assigned the molecular formula $\mathrm{C}_{24} \mathrm{H}_{28} \mathrm{O}_{4}$ by high-resolution electrospray ionization mass spectrometry (HRESIMS) at $\mathrm{m} / \mathrm{z} 379.1906\left([\mathrm{M}-\mathrm{H}]^{-}\right.$, calcd for $\left.\mathrm{C}_{24} \mathrm{H}_{27} \mathrm{O}_{4}, 379.1915\right)$. The UV spectrum of 1 showed absorption maxima at 211 and $285 \mathrm{~nm}$, which was in agreement with a dihydrostilbene chromophore $[17,19]$. The ${ }^{1} \mathrm{H}$ NMR spectrum ( $\triangleright$ Table 1 ) showed signals for a pair of meta-coupled aromatic protons at $\delta_{\mathrm{H}} 6.23$ and $6.07(1 \mathrm{H}$ each, $2 \mathrm{~d}, J=2.3 \mathrm{~Hz}) ; 2$ aromatic singlets at $\delta_{\mathrm{H}} 6.98$ and 6.37 ( $1 \mathrm{H}$ each, $\left.2 \mathrm{~s}\right)$; and a 1,1-dimethylallyl group at $\delta_{\mathrm{H}} 6.24(1 \mathrm{H}, \mathrm{dd}, J=17.5,10.6 \mathrm{~Hz}), 4.97(1 \mathrm{H}$, $\mathrm{dd}, J=17.5,1.6 \mathrm{~Hz}), 4.93(1 \mathrm{H}, \mathrm{dd}, J=10.6,1.6 \mathrm{~Hz})$, and $1.42(6 \mathrm{H}$, s) $[10,17,19]$. The other 11 proton signals showed terminal alkenyl signals at $\delta_{\mathrm{H}} 4.75(1 \mathrm{H}, \mathrm{d}, J=2.3 \mathrm{~Hz})$ and $4.56(1 \mathrm{H}, \mathrm{m}) ; 2$ methylene signals at $\delta_{\mathrm{H}} 2.77(1 \mathrm{H}, \mathrm{dd}, J=16.5,5.5 \mathrm{~Hz}), 2.74(1 \mathrm{H}$, dd, $J=16.5,11.8 \mathrm{~Hz}), 2.84(1 \mathrm{H}, \mathrm{dd}, J=16.2,5.3 \mathrm{~Hz})$, and $2.56(1 \mathrm{H}$, $\mathrm{dd}, J=16.2,11.8 \mathrm{~Hz}) ; 2$ methine signals at $\delta_{\mathrm{H}} 3.28(1 \mathrm{H}, \mathrm{td}$, $J=11.8,5.5 \mathrm{~Hz})$ and $2.87(1 \mathrm{H}, \mathrm{td}, J=11.8,5.3 \mathrm{~Hz})$; as well as the signal for a quaternary methyl at $\delta_{\mathrm{H}} 1.58(3 \mathrm{H}$, s), which were assigned to the 2 coadjacent fragments of $-\mathrm{CH}_{2}-\mathrm{CH}-\mathrm{CH}-\mathrm{CH}_{2}-$ and $-\mathrm{CH}-\mathrm{C}(\mathrm{Me})=\mathrm{CH}_{2}$ by analyses of the ${ }^{1} \mathrm{H}-{ }^{1} \mathrm{H}$ COSY, HSQC, and HMBC spectra (Figs. 9S-13S). Moreover, cyclization of the ali- 
- Table $1{ }^{1} \mathrm{H}$ NMR data for compounds 1-4 and 7.

\begin{tabular}{|c|c|c|c|c|c|}
\hline \multirow{2}{*}{$\begin{array}{l}\text { Posi- } \\
\text { tion }\end{array}$} & \multicolumn{5}{|l|}{$\delta_{\mathrm{H}}(\mathrm{ppm}, \mathrm{J}$ in $\mathrm{Hz})$} \\
\hline & $1^{\mathrm{a}}$ & $2^{b}$ & $3^{b}$ & $4^{b}$ & $7^{b}$ \\
\hline 2 & $6.23(1 \mathrm{H}, \mathrm{d}, 2.3)$ & $6.21(1 \mathrm{H}, \mathrm{d}, 2.3)$ & $6.19(1 \mathrm{H}, \mathrm{d}, 2.3)$ & $6.05(1 \mathrm{H}, \mathrm{d}, 2.4)$ & $6.51(1 \mathrm{H}, \mathrm{d}, 2.5)$ \\
\hline 4 & $6.07(1 \mathrm{H}, \mathrm{d}, 2.3)$ & $6.59(1 \mathrm{H}, \mathrm{d}, 2.3)$ & $6.24(1 \mathrm{H}, \mathrm{d}, 2.3)$ & $6.14(1 \mathrm{H}, \mathrm{d}, 2.4)$ & $6.97(1 \mathrm{H}, \mathrm{d}, 2.5)$ \\
\hline $5 \alpha$ & $2.77(1 \mathrm{H}, \mathrm{dd}, 16.5,5.5)$ & $7.09(1 \mathrm{H}, \mathrm{d}, 16.2)$ & $3.19(1 \mathrm{H}, \mathrm{d}, 4.0)$ & $3.30(1 \mathrm{H}, \mathrm{m})$ & \\
\hline $5 \beta$ & $2.74(1 \mathrm{H}, \mathrm{dd}, 16.5,11.8)$ & & & & \\
\hline 6 & $3.28(1 \mathrm{H}, \mathrm{td}, 11.8,5.5)$ & $7.14(1 \mathrm{H}, \mathrm{d}, 16.2)$ & $2.85(1 \mathrm{H}, \mathrm{dd}, 12.0,4.0)$ & $3.18(1 \mathrm{H}, \mathrm{m})$ & $3.90(1 \mathrm{H}, \mathrm{d}, 4.8)$ \\
\hline 7 & $6.98(1 \mathrm{H}, \mathrm{s})$ & $7.29(1 \mathrm{H}, \mathrm{s})$ & $7.16(1 \mathrm{H}, \mathrm{d}, 8.5)$ & $6.95(1 \mathrm{H}, \mathrm{s})$ & $6.86(1 \mathrm{H}, \mathrm{s})$ \\
\hline 8 & & & $6.31(1 \mathrm{H}, \mathrm{dd}, 8.5,2.5)$ & & \\
\hline 10 & $6.37(1 \mathrm{H}, \mathrm{s})$ & $6.30(1 \mathrm{H}, \mathrm{s})$ & $6.16(1 \mathrm{H}, \mathrm{d}, 2.5)$ & $6.09(1 \mathrm{H}, \mathrm{s})$ & $6.22(1 \mathrm{H}, \mathrm{s})$ \\
\hline 13 & $2.87(1 \mathrm{H}, \mathrm{td}, 11.8,5.3)$ & $5.14(1 \mathrm{H}, \mathrm{br} \mathrm{t}, 6.7)$ & $1.20(1 \mathrm{H}, \mathrm{td}, 12.0,2.8)$ & $2.12(1 \mathrm{H}, \mathrm{ddd}, 10.8,6.9,4.5)$ & $2.41(1 \mathrm{H}, \mathrm{dt}, 11.7,4.7)$ \\
\hline $14 \alpha$ & $2.84(1 \mathrm{H}, \mathrm{dd}, 16.2,5.3)$ & $3.36(2 \mathrm{H}, \mathrm{d}, 6.7)$ & $2.91(1 \mathrm{H}, \mathrm{dd}, 14.3,2.8)$ & $2.68(1 \mathrm{H}, \mathrm{dd}, 17.2,6.9)$ & $3.08(1 \mathrm{H}, \mathrm{dd}, 4.5,16.5)$ \\
\hline $14 \beta$ & $2.56(1 \mathrm{H}, \mathrm{dd}, 16.2,11.8)$ & & $2.01(1 \mathrm{H}, \mathrm{t}, 13.1)$ & $2.18(1 \mathrm{H}, \mathrm{dd}, 17.2,10.8)$ & $2.35(1 \mathrm{H}, \mathrm{dd}, 11.7,16.5)$ \\
\hline $18 a$ & $4.75(1 \mathrm{H}, \mathrm{d}, 2.3)$ & $1.80(3 \mathrm{H}, \mathrm{s})$ & $1.40(3 \mathrm{H}, \mathrm{s})$ & $1.44(3 \mathrm{H}, \mathrm{s})$ & $1.46(3 \mathrm{H}, \mathrm{s})$ \\
\hline $18 b$ & $4.56(1 \mathrm{H}, \mathrm{m})$ & & & & \\
\hline 19 & $1.58(3 \mathrm{H}, \mathrm{s})$ & $1.68(3 \mathrm{H}, \mathrm{s})$ & $1.31(3 \mathrm{H}, \mathrm{s})$ & $1.30(3 \mathrm{H}, \mathrm{s})$ & $1.33(3 \mathrm{H}, \mathrm{s})$ \\
\hline 21 & $1.42(3 \mathrm{H}, \mathrm{s})$ & $1.46(3 \mathrm{H}, \mathrm{s})$ & $1.14(3 \mathrm{H}, \mathrm{s})$ & $1.33(3 \mathrm{H}, \mathrm{s})$ & $1.33(3 \mathrm{H}, \mathrm{s})$ \\
\hline 22 & $1.42(3 \mathrm{H}, \mathrm{s})$ & $1.46(3 \mathrm{H}, \mathrm{s})$ & $0.99(3 \mathrm{H}, \mathrm{s})$ & $1.33(3 \mathrm{H}, \mathrm{s})$ & $1.33(3 \mathrm{H}, \mathrm{s})$ \\
\hline 23 & $6.24(1 \mathrm{H}, \mathrm{dd} 17.5,10.6)$ & $6.25(1 \mathrm{H}, \mathrm{dd}, 17.5,10.7)$ & $5.84(1 \mathrm{H}, \mathrm{dd}, 17.9,10.4)$ & $6.13(1 \mathrm{H}, \mathrm{dd}, 17.0,11.2)$ & $6.14(1 \mathrm{H}, \mathrm{dd}, 10.8,17.4)$ \\
\hline $24 a$ & $4.97(1 \mathrm{H}, \mathrm{dd}, 17.5,1.6)$ & $4.98(1 \mathrm{H}, \mathrm{dd}, 17.5,1.5)$ & $4.95(1 \mathrm{H}, \mathrm{dd}, 17.9,1.3)$ & $4.87(1 \mathrm{H}, \mathrm{m})$ & $4.88(1 \mathrm{H}, \mathrm{dd}, 1.5,17.4)$ \\
\hline $24 b$ & $4.93(1 \mathrm{H}, \mathrm{dd}, 10.6,1.6)$ & $4.95(1 \mathrm{H}, \mathrm{dd}, 10.7,1.5)$ & $4.94(1 \mathrm{H}, \mathrm{dd}, 10.4,1.3)$ & $4.89(1 \mathrm{H}, \mathrm{m})$ & $4.87(1 \mathrm{H}, \mathrm{dd}, 1.5,10.8)$ \\
\hline 25 & & & & $2.33(2 \mathrm{H}, \mathrm{m})$ & \\
\hline 26 & & & & $5.32(1 \mathrm{H}, \mathrm{t}, 7.4)$ & \\
\hline 28 & & & & $1.62(3 \mathrm{H}, \mathrm{s})$ & \\
\hline 29 & & & & $1.75(3 \mathrm{H}, \mathrm{s})$ & \\
\hline
\end{tabular}

a Bruker Avance 600 spectrometer in acetone- $d_{6}$; chemical shifts referred to acetone- $d_{6}\left(\delta_{H} 2.05\right)$. ${ }^{\mathrm{b}}$ Bruker Avance 600 spectrometer in methanol- $d_{4}$; chemical shifts referred to methanol- $d_{4}\left(\delta_{\mathrm{H}} 3.31\right)$.

phatic fragment to form a ring (ring C) was needed to satisfy the 11 degrees of unsaturation of 1 .

The structure of 1 ( $\vee$ Fig. 1 ) was inferred from the HSQC and HMBC data. The HMBC spectrum displayed the correlations of $\mathrm{H}_{3}-21 / 22\left(\delta_{\mathrm{H}} 1.42\right)$ and $\mathrm{H}-23\left(\delta_{\mathrm{H}} 6.24\right)$ with $\mathrm{C}-8\left(\delta_{\mathrm{C}} 125.4\right)$, suggesting that the 1,1-dimethylallyl group was located at C-8. Ring $C$ was fused with ring $A$ at $C-15$ and $C-16$ and linked to $C-17$ of ring $B$, as established by the $\mathrm{HMBC}$ correlations ( $\triangleright$ Fig. 2, Fig. 13S, Supporting Information) from $\mathrm{H}-5\left(\delta_{\mathrm{H}} 2.77\right)$ to $\mathrm{C}-4\left(\delta_{\mathrm{C}} 106.8\right), \mathrm{C}-$ $15\left(\delta_{\mathrm{C}} 115.1\right), \mathrm{C}-16\left(\delta_{\mathrm{C}} 139.6\right)$, and $\mathrm{C}-17\left(\delta_{\mathrm{C}} 122.1\right)$; from $\mathrm{H}-6\left(\delta_{\mathrm{H}}\right.$ $3.28)$ to $C-5\left(\delta_{C} 39.4\right), C-7\left(\delta_{C} 127.8\right), C-11\left(\delta_{C} 154.2\right), C-13\left(\delta_{C}\right.$ 47.8), and $\mathrm{C}-17$; and from $\mathrm{H}-13\left(\delta_{\mathrm{H}} 2.87\right)$ to $\mathrm{C}-15$ and $\mathrm{C}-17$; as well as correlations between $\mathrm{H}_{\alpha} / \mathrm{H}_{\beta}-14\left(\delta_{\mathrm{H}} 2.84 / 2.56\right)$ and $\mathrm{C}-1\left(\delta_{\mathrm{C}}\right.$ 156.4), $C-6\left(\delta_{C} 37.1\right)$, and $C-16$. The fragment of $-\mathrm{C}(\mathrm{Me})=\mathrm{CH}_{2}$ (prop-1-en-2-yl group) was located at $\mathrm{C}-13$ of ring $\mathrm{C}$, which was supported by $\mathrm{HMBC}$ correlations of $\mathrm{H}_{a} / \mathrm{H}_{b}-18\left(\delta_{H} 4.75 / 4.56\right)$ with C-12 ( $\left.\delta_{C} 149.6\right), C-13$ and $C-19\left(\delta_{C} 18.8\right)$; and $\mathrm{H}-13$ with C-12, C$18\left(\delta_{C} 111.6\right)$, and $C-19$. The substitution patterns of rings $A$ and $B$ were deduced by the HMBC correlations shown in $>$ Fig. 2 . The relative configuration between $\mathrm{C}-6$ and $\mathrm{C}-13$ was assigned as trans in view of the diaxial coupling constant $J_{6,13}=11.8 \mathrm{~Hz}$ [19], which was supported by NOESY correlations of $\mathrm{H}-6$ with $\mathrm{H}_{a} / \mathrm{H}_{b}-18$ and $\mathrm{H}_{3}-19$ ( $\triangleright$ Fig. 3). No optical activity or circular dichroism was detected, indicating that 1 was obtained as a racemate. This was supported by chiral HPLC analysis of 1 over a Phenomenex Lux Cellulose- 2 column $(5 \mu \mathrm{M}$, i.d. $250 \times 4.6 \mathrm{~mm})$ using acetonitrile$\mathrm{H}_{2} \mathrm{O}(3: 1, \mathrm{v} / \mathrm{v})$ with a flow rate of $1.2 \mathrm{~mL} / \mathrm{min}$, displaying 2 peaks with an integration ratio of about $1: 1$. Thus, the structure of 1 was elucidated as $[6 S(R), 7 S(R)]-6$-[2,4-dihydroxy-5-(1,1-dimethylallyl)phenyl]-7-(prop-1-en-2-yl)-5,6,7,8-tetrahydronaphthalene-

\section{1,3-diol and it was named $( \pm)$-styrastilbene A.}

Compound 2, a yellow amorphous powder, was assigned the molecular formula $\mathrm{C}_{24} \mathrm{H}_{28} \mathrm{O}_{4}$ by HRESIMS at $\mathrm{m} / \mathrm{z} 379.1933$ $\left([\mathrm{M}-\mathrm{H}]^{-}\right.$, calcd for $\left.\mathrm{C}_{24} \mathrm{H}_{27} \mathrm{O}_{4}, 379.1915\right)$. The ${ }^{1} \mathrm{H}$ NMR spectrum exhibited signals for 2 meta-coupled aromatic protons at $\delta_{\mathrm{H}} 6.59$ $(1 \mathrm{H}, \mathrm{d}, J=2.3 \mathrm{~Hz})$ and $6.21(1 \mathrm{H}, \mathrm{d}, J=2.3 \mathrm{~Hz}) ; 2$ aromatic singlets at $\delta_{\mathrm{H}} 7.29(1 \mathrm{H}, \mathrm{s})$ and $6.30(1 \mathrm{H}, \mathrm{s})$; a set of signals for a 1,1-dimethylallyl (prenyl) group at $\delta_{\mathrm{H}} 6.25(1 \mathrm{H}$, dd, $J=17.5,10.7 \mathrm{~Hz})$, $4.98(1 \mathrm{H}, \mathrm{dd}, J=17.5,1.5 \mathrm{~Hz}), 4.95(1 \mathrm{H}, \mathrm{dd}, J=10.7,1.5 \mathrm{~Hz})$, and $1.46(6 \mathrm{H}, \mathrm{s})$; as well as a set of signals for a 3-methyl-2-buten$\mathrm{yl}$ (prenyl) group at $\delta_{\mathrm{H}} 5.14(1 \mathrm{H}, \mathrm{br} \mathrm{t}, J=6.7 \mathrm{~Hz}), 3.36(2 \mathrm{H}, \mathrm{d}$, $J=6.7 \mathrm{~Hz}), 1.80(3 \mathrm{H}, \mathrm{s})$, and $1.68(3 \mathrm{H}, \mathrm{s})$. The 2 proton signals at 

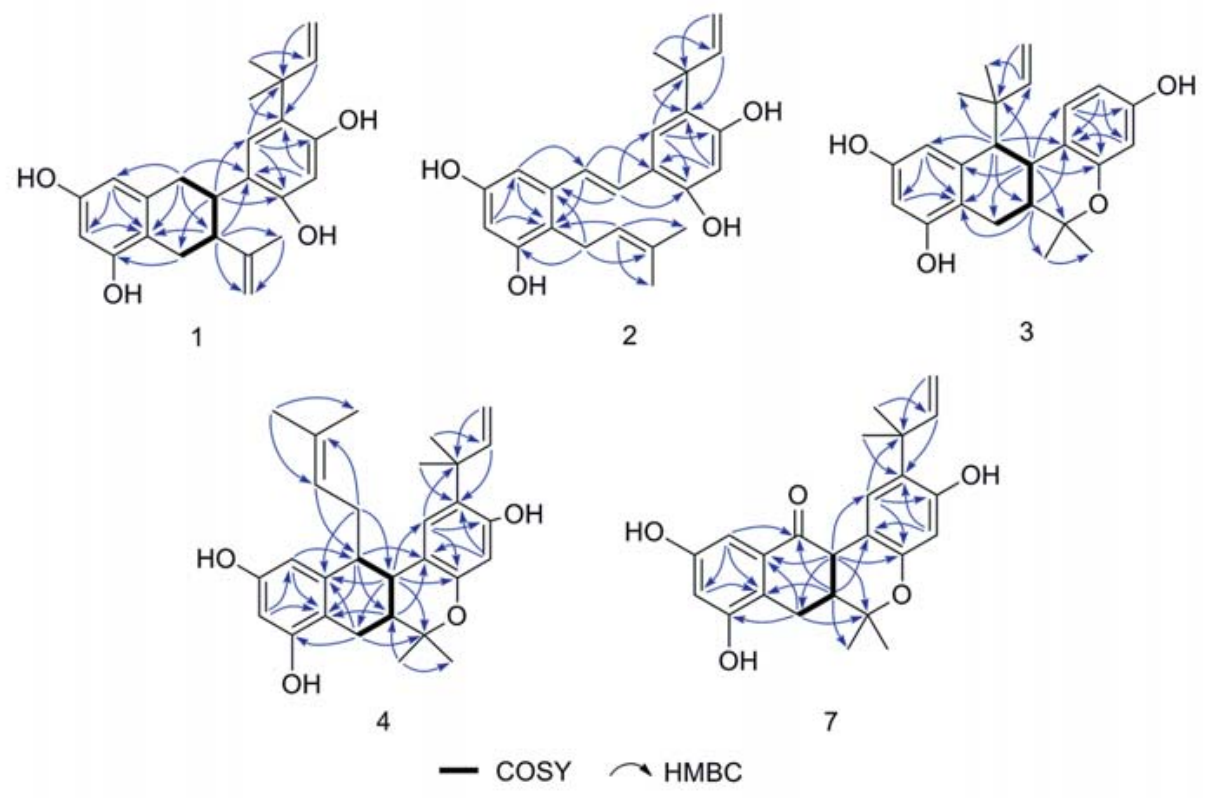

- Fig. 2 Key HMBC $(\mathrm{H} \rightarrow \mathrm{C})$ and COSY correlations of compounds 1-4 and 7.

$\delta_{\mathrm{H}} 7.14(1 \mathrm{H}, \mathrm{d}, \mathrm{J}=16.2 \mathrm{~Hz})$ and $7.09(1 \mathrm{H}, \mathrm{d}, J=16.2 \mathrm{~Hz})$ were unambiguously assigned as a pair of trans 1,2-disubstitued olefinic protons of typical stilbenoids [20,21], supported by the presence of characteristic methine $\mathrm{sp}^{2}$ carbon signals at $\delta \mathrm{c} 126.2$ and 124.3 in ${ }^{13} \mathrm{C}$ NMR ( $\vee$ Table 2) and DEPT spectra (Fig. 22S, Supporting Information) of 2 . These NMR data suggested that 2 was a stilbene derivative with diprenyl substitution. Interpretation of the HSQC and $\mathrm{HMBC}$ spectra allowed the determination of the substitution pattern and the full assignment of ${ }^{1} \mathrm{H}$ and ${ }^{13} \mathrm{C}$ NMR signals. The 2 free prenyl groups were located at $\mathrm{C}-8$ and $\mathrm{C}-15$, respectively, as established by the following $\mathrm{HMBC}$ correlations: from $\mathrm{H}_{2}-14$

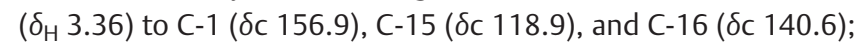
from $\mathrm{H}-13\left(\delta_{\mathrm{H}} 5.14\right)$ to $\mathrm{C}-15$; from $\mathrm{H}_{3}-21 / 22\left(\delta_{\mathrm{H}} 1.46\right)$ to $\mathrm{C}-8(\delta \mathrm{C}$ $127.3)$; and from $\mathrm{H}-23\left(\delta_{H} 6.25\right)$ to $\mathrm{C}-8(\delta \mathrm{c} 127.3)$. The substitution of rings $A$ and $B$ was inferred from the $\mathrm{HMBC}$ correlations shown in $>$ Fig. 2 . Thus, the structure of 2 was established as $(E)$ 5-(2,4-dihydroxy-5-(1,1-dimethylallyl)styryl)-4-(3-methylbut-2en-1-yl)benzene-1,3-diol, and it was named styrastilbene B.

Compound 3, a yellow amorphous powder, was assigned the molecular formula $\mathrm{C}_{24} \mathrm{H}_{28} \mathrm{O}_{4}$ by HRESI at $\mathrm{m} / \mathrm{z} 379.1907\left([\mathrm{M}-\mathrm{H}]^{-}\right.$, calcd for $\left.\mathrm{C}_{24} \mathrm{H}_{27} \mathrm{O}_{4}, 379.1915\right)$. The ${ }^{1} \mathrm{H}$ NMR spectrum showed signals for an aromatic $A B X$ spin system (ring $B$ ) at $\delta_{\mathrm{H}} 7.16(1 \mathrm{H}$, $\mathrm{d}, J=8.5 \mathrm{~Hz}), 6.31(1 \mathrm{H}, \mathrm{dd}, J=8.5,2.5 \mathrm{~Hz})$, and $6.16(1 \mathrm{H}, \mathrm{d}$, $J=2.5 \mathrm{~Hz}$ ); 2 meta-coupled aromatic protons (ring A) at $\delta_{\mathrm{H}} 6.24$ $(1 \mathrm{H}, \mathrm{d}, J=2.3 \mathrm{~Hz})$ and $6.19(1 \mathrm{H}, \mathrm{d}, J=2.3 \mathrm{~Hz})$; as well as signals for a 1,1-dimethylallyl group at $\delta_{\mathrm{H}} 5.84(1 \mathrm{H}$, dd, J=17.9, $10.4 \mathrm{~Hz}), 4.95(1 \mathrm{H}, \mathrm{dd}, J=17.9,1.3 \mathrm{~Hz})$, and $4.94(1 \mathrm{H}$, dd, $J=10.4,1.3 \mathrm{~Hz}$ ). Moreover, analysis of the ${ }^{1} \mathrm{H}-{ }^{1} \mathrm{H}$ COSY, HSQC and $\mathrm{HMBC}$ spectra allowed assignment of the following 11 aliphatic proton signals to the 2 coadjacent fragments of $-\mathrm{CH}-\mathrm{CH}-\mathrm{CH}-\mathrm{CH}_{2}-$ and $-\mathrm{CH}-\mathrm{C}\left(\mathrm{Me}_{2}\right) \mathrm{O}-: \delta_{\mathrm{H}} 3.19(1 \mathrm{H}, \mathrm{d}, J=4.0 \mathrm{~Hz})$, $2.85(1 \mathrm{H}, \mathrm{dd}, J=12.0,4.0 \mathrm{~Hz}), 1.20(1 \mathrm{H}, \mathrm{td}, J=12.0,2.8 \mathrm{~Hz})$,

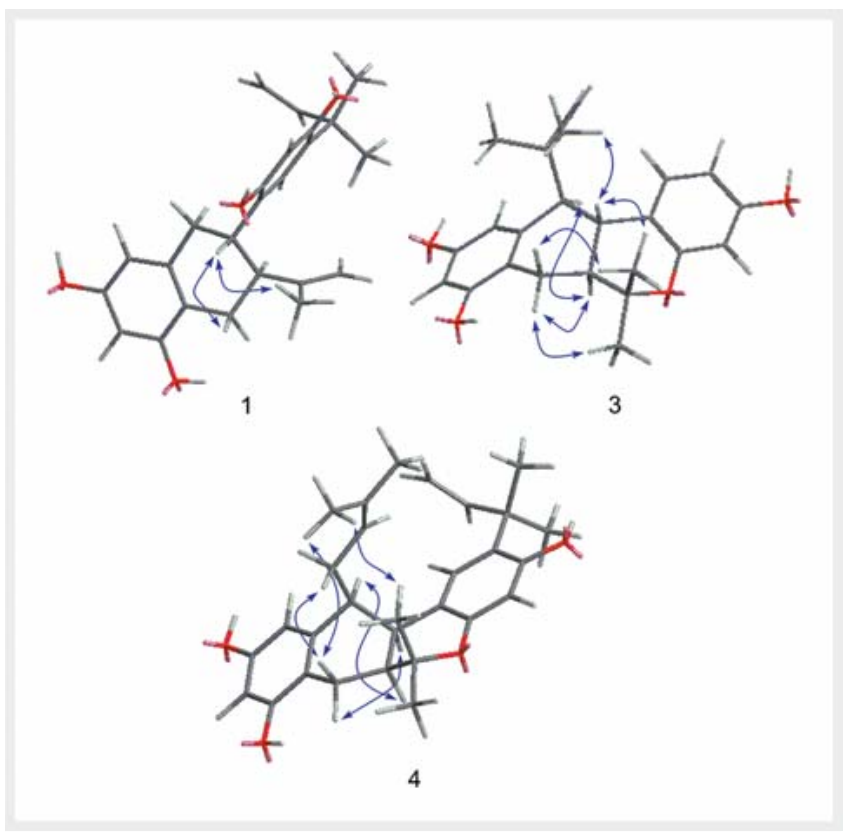

- Fig. 3 Key NOESY correlations of compounds 1, 3, and 4.

$2.91(1 \mathrm{H}, \mathrm{dd}, J=14.3,2.8 \mathrm{~Hz}), 2.01(1 \mathrm{H}, \mathrm{t}, J=13.1 \mathrm{~Hz}), 1.40$ $(3 \mathrm{H}, \mathrm{s})$, and $1.31(3 \mathrm{H}, \mathrm{s})$. These ${ }^{1} \mathrm{H}$ NMR data ( Table 1$)$ are very similar to those of the known compound 8 [10] isolated from A. nanchuanensis. The main difference was the extra appearance of an aromatic proton signal at $\delta_{\mathrm{H}} 6.31$ in 3 and the disappearance of an aliphatic proton signal assigned for $\mathrm{H}-5$ at $\delta_{\mathrm{H}} 2.47$ in 8 . This strongly indicated that the 1,1-dimethylallyl group substitution took place at C-5 instead of C-8 (ring B), which was supported by 
- Table $2{ }^{13} \mathrm{C}$ NMR data for compounds $1-4$ and 7.

\begin{tabular}{|c|c|c|c|c|c|}
\hline \multirow{2}{*}{$\begin{array}{l}\text { Posi- } \\
\text { tion }\end{array}$} & \multicolumn{5}{|c|}{$\delta_{\mathrm{C}}(\mathrm{ppm})$} \\
\hline & $1^{\mathrm{a}}$ & $2^{b}$ & $3^{b}$ & $4^{b}$ & $7^{b}$ \\
\hline 1 & 156.4 & 156.9 & 155.0 & 156.5 & 157.3 \\
\hline 2 & 100.7 & 102.2 & 101.5 & 101.0 & 109.2 \\
\hline 3 & 156.6 & 156.6 & 155.7 & 156.2 & 157.5 \\
\hline 4 & 106.8 & 104.2 & 111.9 & 108.0 & 104.7 \\
\hline 5 & 39.4 & 124.3 & 51.6 & 43.0 & 200.0 \\
\hline 6 & 37.1 & 126.2 & 35.4 & 33.2 & 45.9 \\
\hline 7 & 127.8 & 126.2 & 127.2 & 125.9 & 127.1 \\
\hline 8 & 125.4 & 127.3 & 107.6 & 127.2 & 128.3 \\
\hline 9 & 154.5 & 157.5 & 157.5 & 155.7 & 157.3 \\
\hline 10 & 104.6 & 104.8 & 104.5 & 105.1 & 105.6 \\
\hline 11 & 154.2 & 155.3 & 156.2 & 154.2 & 153.9 \\
\hline 12 & 149.6 & 130.6 & 80.1 & 77.7 & 76.9 \\
\hline 13 & 47.8 & 125.8 & 50.0 & 34.7 & 40.9 \\
\hline 14 & 30.4 & 25.3 & 24.7 & 21.4 & 20.6 \\
\hline 15 & 115.1 & 118.9 & 119.9 & 114.5 & 123.3 \\
\hline 16 & 139.6 & 140.6 & 140.1 & 141.6 & 133.4 \\
\hline 17 & 122.1 & 117.3 & 121.5 & 113.5 & 105.8 \\
\hline 18 & 111.6 & 18.0 & 29.6 & 26.9 & 26.5 \\
\hline 19 & 18.8 & 25.9 & 22.8 & 26.7 & 25.7 \\
\hline 20 & 40.7 & 41.1 & 43.9 & 41.2 & 41.1 \\
\hline 21 & 27.6 & 27.8 & 26.3 & $27.5^{\dagger}$ & $27.5^{*}$ \\
\hline 22 & 27.7 & 27.8 & 26.6 & $27.6^{\dagger}$ & $27.6^{\ddagger}$ \\
\hline 23 & 149.6 & 149.7 & 148.5 & 149.9 & 149.4 \\
\hline 24 & 110.0 & 110.3 & 112.4 & 110.0 & 110.2 \\
\hline 25 & & & & 37.4 & \\
\hline 26 & & & & 124.4 & \\
\hline 27 & & & & 133.9 & \\
\hline 28 & & & & 18.2 & \\
\hline 29 & & & & 26.0 & \\
\hline
\end{tabular}

${ }^{a}$ Bruker Avance 600 spectrometer in acetone- $d_{6}$; chemical shifts referred to acetone- $d_{6}\left(\delta_{C} 29.92\right)$. ${ }^{\mathrm{b}}$ Bruker Avance 600 spectrometer in methanol$d_{4}$; chemical shifts referred to methanol- $d_{4}\left(\delta_{C} 49.00\right)$; assignments with identical superscripts $(\dagger, \ddagger)$ are interchangeable.

the HMBC correlations ( $\bullet$ Fig. 2) from $\mathrm{H}_{3}-21\left(\delta_{\mathrm{H}} 1.14\right)$ and $\mathrm{H}_{3}-22$ $\left(\delta_{H} 0.99\right)$ to $C-5\left(\delta_{C} 51.6\right)$ and from $\mathrm{H}-23\left(\delta_{H} 5.84\right)$ to $\mathrm{C}-5$. The substitutions of rings $A$ and $B$ were established by the HMBC couplings shown in $>$ Fig. 2 . Similar to 1 , the relative configurations of $\mathrm{C}-6$ and $\mathrm{C}-13$ were assigned as trans in view of the diaxial $\int_{6,13}$ value of $12.0 \mathrm{~Hz}$ [19]. In addition, the NOESY correlations of $\mathrm{H}_{\alpha^{-}}$ $14\left(\delta_{\mathrm{H}} 2.91\right)$ with $\mathrm{H}-5\left(\delta_{\mathrm{H}} 3.19\right), \mathrm{H}-13\left(\delta_{\mathrm{H}} 1.20\right)$, and $\mathrm{H}_{3}-18\left(\delta_{\mathrm{H}}\right.$ 1.40); $\mathrm{H}_{\beta}-14\left(\delta_{H} 2.01\right)$ with $\mathrm{H}_{3}-19\left(\delta_{H} 1.31\right)$; as well as correlations of $\mathrm{H}-6\left(\delta_{\mathrm{H}} 2.85\right)$ with $\mathrm{H}_{3}-19, \mathrm{H}_{3}-21$, and $\mathrm{H}_{3}-22$ were observed, suggesting that $\mathrm{H}-5, \mathrm{H}_{\alpha}-14$, and $\mathrm{H}-13$ were on the same side. Compound 3 was also a racemate, as indicated by chiral HPLC analysis (analytical method similar to that for 1 ) displaying 2 peaks with an integration ratio of about $1: 1$. Thus, the structure of 3 was established as $[6 \mathrm{a} S(R), 12 R(S), 12 \mathrm{a} S(R)]-6,6$-dimethyl-12-(1,1dimethylallyl)-6a,7,12,12a-tetrahydro-6H-naphtho[2,3-c]chromene-3,8,10-triol, and it was named ( \pm )-styrastilbene $C$.

Compound 4, a yellow amorphous powder, was assigned the molecular formula $\mathrm{C}_{29} \mathrm{H}_{36} \mathrm{O}_{4}$ by HRESIMS at $\mathrm{m} / \mathrm{z} 447.2526$ ([M- $]^{-}$, calcd for $\left.\mathrm{C}_{29} \mathrm{H}_{35} \mathrm{O}_{4}, 447.2541\right)$. The ${ }^{1} \mathrm{H}$ NMR spectrum of 4 was similar to that of the known compound 6 [10]. A comparison of the ${ }^{1} \mathrm{H}$ NMR data of 4 with those of 6 revealed that the main difference was the presence of an extra set of proton signals for the 3-methyl-2-butenyl group in 4 . This suggested that 4 was a stilbene derivative with triprenyl substitution. Interpretation of the HSQC and HMBC spectra of $\mathbf{4}$ showed the substitution pattern and fully assigned all ${ }^{1} \mathrm{H}$ and ${ }^{13} \mathrm{C} \mathrm{NMR}$ signals. The 3-methyl-2-butenyl group and 1,1-dimethylallyl group were located at C-5 and C-8, respectively, as established by HMBC correlations ( $\triangleright$ Fig. 2 ) from $\mathrm{H}_{2}-25\left(\delta_{\mathrm{H}} 2.33\right)$ to $\mathrm{C}-5\left(\delta_{\mathrm{C}} 43.0\right), \mathrm{C}-6\left(\delta_{\mathrm{C}} 33.2\right)$, and $\mathrm{C}-16\left(\delta_{\mathrm{C}}\right.$ 141.6); from $\mathrm{H}-26\left(\delta_{\mathrm{H}} 5.32\right)$ to $\mathrm{C}-5$; and from $\mathrm{H}_{3}-21 / 22\left(\delta_{\mathrm{H}} 1.33\right)$ and $\mathrm{H}-23\left(\delta_{H} 6.13\right)$ to $\mathrm{C}-8\left(\delta_{C} 127.2\right)$. For the relative configuration of 4 , a cis arrangement between $\mathrm{H}-6$ and $\mathrm{H}-13$ was indicated by the $J_{6,13}$ value of $4.5 \mathrm{~Hz}[17,19]$. In addition, the NOESY cross peaks of $\mathrm{H}_{\alpha}-14\left(\delta_{\mathrm{H}} 2.68\right)$ with $\mathrm{H}-6\left(\delta_{\mathrm{H}} 3.18\right)$ and $\mathrm{H}-13\left(\delta_{\mathrm{H}} 2.12\right)$; $\mathrm{H}-13$ with $\mathrm{H}-5\left(\delta_{\mathrm{H}} 3.30\right)$; and $\mathrm{H}_{\beta^{-}}-14\left(\delta_{\mathrm{H}} 2.18\right)$ with $\mathrm{H}_{2}-25$ and $\mathrm{H}_{3}$ $28\left(\delta_{H} 1.62\right)$ suggested that $\mathrm{H}-5, \mathrm{H}-6$ and $\mathrm{H}-13$ were on the same side. Compound 4 was also a racemate, as shown by chiral HPLC analysis (analytical method similar to that for 1 ). Thus, the structure of 4 was established as [6aS(R),12S(R),12a $R(S)]$-6,6-dimethyl12-(3-methylbut-2-en-1-yl)-2-(1,1-dimethylallyl)-6a,7,12,12atetrahydro-6H-naphtho[2,3-c]chromene-3,8,10-triol, and it was named $( \pm$ )-styrastilbene $\mathrm{D}$.

Compound 7, a yellow amorphous powder, was assigned the molecular formula $\mathrm{C}_{24} \mathrm{H}_{26} \mathrm{O}_{5}$ by HRESIMS at $\mathrm{m} / \mathrm{z} 395.1855$ $\left([\mathrm{M}+\mathrm{H}]^{+}\right.$, calcd for $\left.\mathrm{C}_{24} \mathrm{H}_{27} \mathrm{O}_{5}, 395.1853\right)$. The ${ }^{1} \mathrm{H}$ NMR spectrum of 7 was highly similar to that of the known compound 6 [10], except for the absence of an aliphatic proton signal at $\delta_{H} 5.14$ assigned for $\mathrm{H}-5$ in 6 . A further comparison of the ${ }^{13} \mathrm{C}$ NMR data of 7 with those of 6 showed that the oxygenated methine $\mathrm{sp}^{3}$ carbon signal at $\delta_{C} 69.5$ assigned to $C-5$ of 6 disappeared in 7 and was replaced with a carbonyl carbon signal at $\delta_{C} 200.0$. This suggested that 7 was an oxygenated derivative of 6 resulting from further oxygenation of $\mathrm{C}-5$, which was confirmed by the HMBC correlations of $\mathrm{H}-4\left(\delta_{\mathrm{H}} 6.97\right)$ with $\mathrm{C}-2\left(\delta_{\mathrm{C}} 109.2\right), \mathrm{C}-3\left(\delta_{\mathrm{C}} 157.5\right), \mathrm{C}-5\left(\delta_{\mathrm{C}}\right.$ $200.0)$, and $\mathrm{C}-15\left(\delta_{\mathrm{C}} 123.3\right) ; \mathrm{H}-6\left(\delta_{\mathrm{H}} 3.90\right)$ with $\mathrm{C}-5, \mathrm{C}-11\left(\delta_{\mathrm{C}}\right.$ $153.9), C-12\left(\delta_{C} 76.9\right), C-13\left(\delta_{C} 40.9\right), C-14\left(\delta_{C} 20.6\right), C-16\left(\delta_{C}\right.$ $133.4)$, and $\mathrm{C}-17\left(\delta_{\mathrm{C}} 105.8\right)$; and $\mathrm{H}-13\left(\delta_{\mathrm{H}} 2.41\right)$ with $\mathrm{C}-5, \mathrm{C}-6\left(\delta_{\mathrm{C}}\right.$ 45.9), C-14, C-15, C-17, and C-18 $\left(\delta_{C} 26.5\right)$. The relative orientation of $\mathrm{H}-6$ and $\mathrm{H}-13$ was assigned as synperiplanar because of the $J_{6,13}$ value of $4.8 \mathrm{~Hz}[17,19]$. Compound 7 was also a racemate, as shown by chiral HPLC analysis (analytical method similar to that for 1 ). Thus, the structure of 7 was established as $[6 a S(R), 12 a R$ (S)]-8,10-dihydroxy-6,6-dimethyl-2-(1,1-dimethylallyl)-6a,7-dihydro-6H-aphtho[2,3-c]chromen-12(12aH)-one, and it was named $( \pm)$-styrastilbene $\mathrm{E}$.

The structures of the 4 known compounds ( $5,6,8$, and 9 ) were identified as shown in $>$ Fig. 1 by comparison of their NMR and MS data with those reported in the literature. It is noteworthy that compounds 3-8 represent a class of structurally unusual prenylated stilbene derivatives with a unique tetracyclic ring system. 


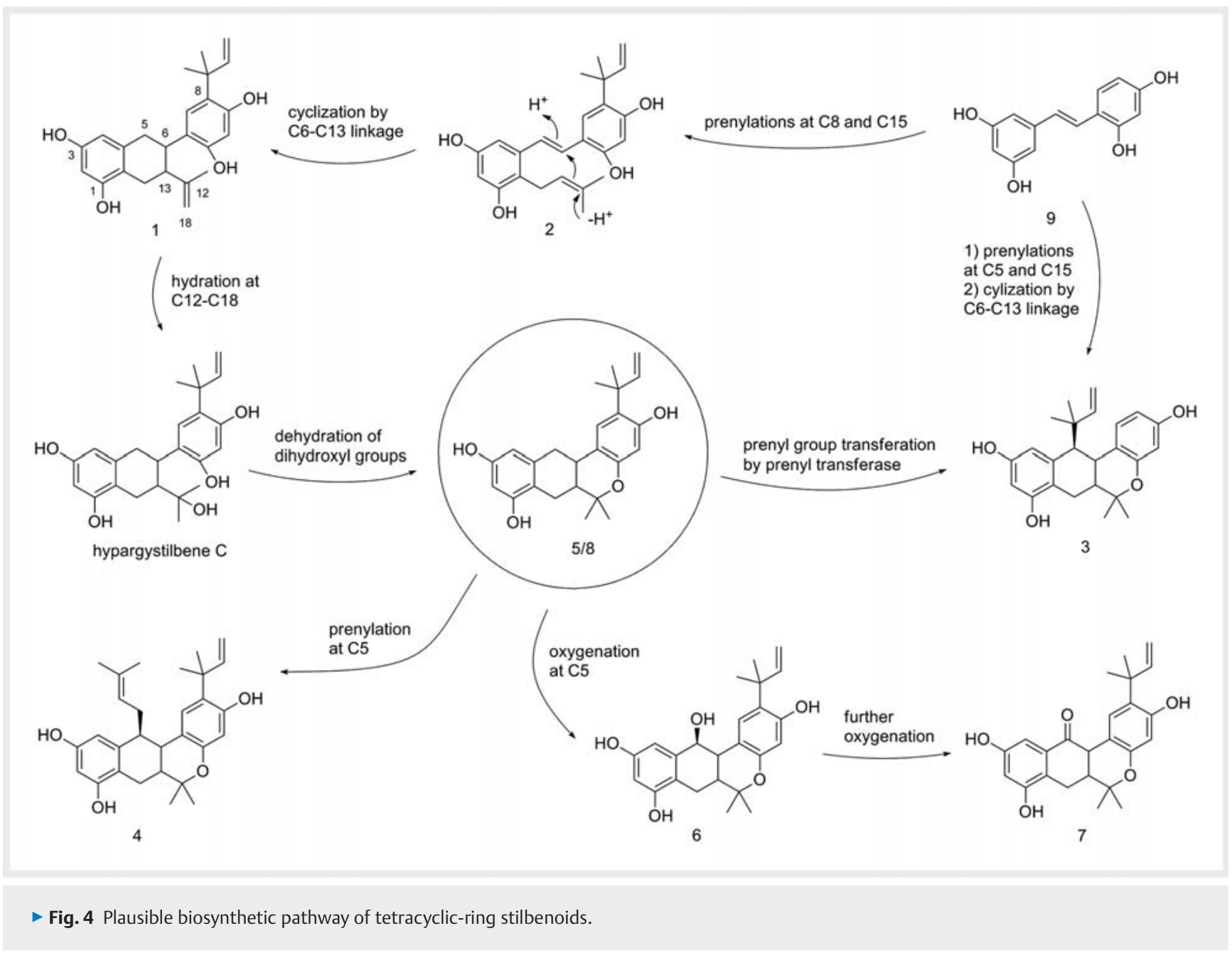

To the best of our knowledge, the occurrence of natural products structurally similar to 3-8 has been strictly limited to the members of the genus Artocarpus and only 4 of such compounds were reported previously $[10,17,19]$. A biogenetic pathway for this class of unusual stilbenoids was previously proposed, which suggested that the 2 aliphatic rings ( $B$ and $C$ ) of the tetracyclic ring system are formed in a 1-step coupling reaction [17]. In this study, a series of stilbenoids were obtained, which allows us to suggest a more plausible biogenetic pathway than the one previously proposed. It is suggested that multistep reactions, including prenylation, partial cyclization of the prenyl group, hydration of olefinic bond, and dehydration of 2 hydroxyl groups, are involved in the process of formation of the tetracyclic ring system ( $\bullet$ Fig. 4 ).

All 9 compounds were evaluated for their abilities to inhibit PTP1B activity. As shown in - Table 3, compound 2 revealed the highest PTP1B inhibition among the isolated compounds, with an $I C_{50}$ value of 2.40 (95\% confidence interval $\left.[\mathrm{CI}]: 2.21-2.59\right) \mu \mathrm{M}$, which was comparable to that of the positive control, ursolic acid $\left(\mathrm{IC}_{50}=5.16\right.$ [95\% Cl: 4.93-5.39] $\left.\mu \mathrm{M}\right)$. Compounds 1, 3, 8, and 9 also exhibited significant inhibitory activity against PTP1B with $\mathrm{IC}_{50}$ values ranging from 4.52 (95\% Cl: $\left.4.24-4.80\right)$ to 8.80 (95\% Cl: 8.28-9.32) $\mu \mathrm{M}$, while compounds $4-7$ were found to be weak or inactive. Interestingly, this suggests that the relative orienta- tion of $\mathrm{H}-6$ and $\mathrm{H}-13$ in these compounds might contribute to their abilities to inhibit PTP1B. Thus, a trans arrangement between $\mathrm{H}-6$ and $\mathrm{H}-13$ appears to be favorable for the suppression of PTP1B activity, as indicated by the difference in activity among the compounds with a trans $(1,3$, and 8 ) or cis (4-7) arrangement of $\mathrm{H}-6 / \mathrm{H}-13$ ( $\vee$ Table 3 ).

Kinetic analyses using Lineweaver-Burk and Dixon plots were further performed to elucidate the type of PTP1B inhibition and determine inhibition constants ( $K_{i}$ values) of the active stilbene derivatives (1-3, 8, and 9). In the Lineweaver-Burk plot method, the crossing of regression lines of the inhibitors in the $x y$ region indicates mixed inhibition, and the intersection of the lines at the same point on the $x$-axis or $y$-axis represents noncompetitive or competitive inhibition, respectively [22]. All tested compounds inhibited PTP1B in a mixed manner ( $\vee$ Table 3 ), as suggested by the fact that the plotted lines of the tested inhibitors intersected in the $x y$ region ( $\triangleright$ Fig. $\mathbf{5}$ ). Our results indicated that these 5 active compounds may bind to not only the conventional catalytic domain but also an additional binding site of the PTP1B enzyme. In the Dixon plot method, $K_{i}$ values were determined and were in the range of 1.82-8.13 $\mu \mathrm{M}$. Among them, compound 1, possessing a lower $K_{i}$ value, might be promising for the development of a mixed PTP1B inhibitor. 
- Table 3 Inhibition effects of compounds 1-9 against PTP1B.

\begin{tabular}{|c|c|c|}
\hline Compounds & $\mathrm{IC}_{50}{ }^{\mathrm{a}}(\mu \mathrm{M})$ & Inhibition type $\left(K_{i}^{\mathrm{a}}, \mu \mathrm{M}\right)$ \\
\hline 1 & $4.52(4.24-4.80)$ & mixed [1.95 (1.81-2.09)] \\
\hline 2 & $2.40(2.21-2.59)$ & mixed [1.82 (1.73-1.91)] \\
\hline 3 & $8.23(7.54-8.92)$ & mixed $[3.28(2.94-3.62)]$ \\
\hline 4 & $>50$ & $-\mathrm{b}$ \\
\hline 5 & $>50$ & $-{ }^{b}$ \\
\hline 6 & $>50$ & $-{ }^{\mathrm{b}}$ \\
\hline 7 & $>50$ & $-\mathrm{b}$ \\
\hline 8 & $8.80(8.28-9.32)$ & mixed $[8.13(7.41-8.85)]$ \\
\hline 9 & $8.43(8.03-8.83)$ & mixed [3.41 (3.10-3.72)] \\
\hline Ursolic acidc & $5.16(4.93-5.39)$ & $-{ }^{\mathrm{b}}$ \\
\hline
\end{tabular}

An in silico molecular docking simulation was employed to estimate the interaction between PTP1B and these stilbene derivatives (1-3, 8, and 9) and known inhibitors (ligand C [a catalytic inhibitor] and ligand $\mathrm{A}$ [an allosteric inhibitor]). The results showed that the enzyme-inhibitor complexes of tested compounds or ligand $\mathrm{C}$ were stably positioned in the catalytic site of PTP1B, with negative binding energies of $-5.84,-6.11,-5.45,-5.56$, and $-5.56 \mathrm{kcal} / \mathrm{mol}$ ( $\triangleright$ Table 4$)$, respectively. The ligand interactions of the 5 tested compounds with PTP1B were elucidated to involve the simultaneous establishment of multiple hydrophobic contacts and/or hydrogen bonds in the catalytic site, as illustrated in $>\mathbf{T a -}$ ble 4 and Fig. 6 . For example, catalytic inhibition by 1 against PTP1B exhibited $4 \mathrm{H}$-bonds with 4 residues Gly183, Cys215, Gly220, and Arg221. The hydroxyl group in C-3 (ring A) of 1 is involved in the strong $\mathrm{H}$-bonding interaction with the sulfur group of Cys215 and the 2 nitrogen groups from each of Gly220 and Arg221, showing bond distances of 3.05, 3.19, and $3.22 \AA$, respectively. The strongest $\mathrm{H}$-bond interaction, however, was observed between the nitrogen group of Gly183 and the hydroxyl group in C-9 (ring B) of 1, with a bond distance of $2.86 \AA$. In addition, 1 also displayed hydrophobic interactions with some reported catalytic residues of PTP1B, such as Tyr46, Trp179, and GIn266 [23, 24], which further stabilized the enzyme-inhibitor interaction ( $\bullet$ Fig. 6 , Table 4 ).

Many studies have indicated that the binding of ligand with residues in the $\alpha 3$ and $\alpha 7$ helices of PTP1B could lead to allosteric inhibition of enzyme activity [8, 23-25]. Leu192, Asn193, Phe196, Phe280 residues were frequently reported as the interacting residues for some PTP1B allosteric inhibitors [23-25]. From our docking results, the enzyme-inhibitor complexes of all tested compounds at the allosteric site of PTP1B exhibited high binding affinity $(-4.54,-5.96,-4.66,-5.14$, and $-5.21 \mathrm{kcal} / \mathrm{mol}$, respectively) ( $\triangleright$ Table 4). Specifically, Van der Waals contacts were observed to be the predominant binding mode compared with $\mathrm{H}$-bond interactions, as illustrated in $\mathbf{r}$ Fig. 7. In addition, the 5 tested compounds and ligand $A$ interacted with the same allosteric residues Phe280 (in the $\alpha 7$ helix) and Ala189, Leu192, and Phe196 (in the $\alpha 3$ helix) via hydrophobic interactions. These in silico results are in accordance with the results of in vitro kinetic analysis and indicated that stilbene derivatives $1-3,8$, and 9 could bind tightly at catalytic and allosteric sites of PTP1B.

It is worth noting that several critical catalytic residues related to selectivity for PTP1B inhibitors over T-cell protein tyrosine phosphatase (TCPTP), the phosphatase with the highest homology to PTP1B, were observed to be involved in the hydrophobic interactions with these stilbene derivatives, such as Lys116 and Asp181 [26] for 1; Arg24 and Met258 [27] for 2; Lys116, Asp181, and Ser216 [26] for 3; Ser216 [26] for 8; and Ser216 [26] for 9 ( $\vee$ Table 4). These interactions suggest that the PTP1B inhibition by these compounds might occur selectively over TCPTP.

In conclusion, 5 new prenylated stilbenes were isolated from A. styracifolius and structurally characterized. A new plausible biosynthetic pathway for the formation of these unusual tetracyclicring stilbenes is proposed. Five isolates were identified as PTP1B inhibitors and their mode of inhibition was revealed by kinetic analysis to be mixed type. Furthermore, the mode of binding of the active compounds $(1-3,8$, and 9$)$ with PTP1B enzyme was revealed by molecular docking simulation, which supported the above results. The present results suggest that these prenylated stilbenes might have a potential to be further developed for the management of T2DM. However, additional studies will be required to confirm their selectivity and investigate their in vivo efficacy, drug-likeness properties, and bioavailability.

The spectra (1D and 2D NMR, UV, IR, and HRESIMS) of the new compounds 1 (Fig. 1S-15S), 2 (Fig. 16S-24S), 3 (Fig. 25S-34S), 4 (Fig. 35S-47S), and 7 (Fig. 48S-58S) are available as Supporting Information.

\section{Materials and Methods}

\section{General experimental procedures}

Infrared (IR) spectra were acquired from a Shimadzu Iraffinity-1 spectrometer with a $\mathrm{KBr}$ disk. UV spectra were measured on a Shimadzu UV-1800 spectrophotometer. Optical rotations were determined on a JASCO P-1020 polarimeter. NMR spectra were recorded on a Bruker Avance 600 spectrometer and processed through the processing software Bruker TOPSPIN (version 2.1). HRESIMS analyses were performed on an AB SCIEX Triple TOF 5600 + mass spectrometer or SHIMADZU LCMS-IT-TOF mass spectrometer. CC was performed on silica gel $(10-40 \mu \mathrm{m}$, Qingdao Marine Chemical Factory), ODS (75-150 $\mu \mathrm{m}$; YMC Co.), Sephadex LH-20 (GE Healthcare Bio-Sciences), and MCI GEL CHP20P (75$150 \mu \mathrm{m}$; Mitsubishi Chemical Co.). Precoated thin-layer chromatography plates with silica gel $G_{254}$ (Qingdao Marine Chemical Factory) were used to check the purity of isolates after spraying with $10 \% \mathrm{H}_{2} \mathrm{SO}_{4}$ in $\mathrm{EtOH}(\mathrm{v} / \mathrm{v})$, followed by heating. PHPLC was performed on a liquid chromatography system (LC3000 system; Beijing Chuangxintongheng Science \& Technology Co., Ltd.) equipped with an ODS column $(5 \mu \mathrm{m}$, i. d. $20 \mathrm{~mm} \times 250 \mathrm{~mm}$; YMC Co.). $p$-Nitrophenyl phosphate ( $p$-NPP), ethylenediaminetetraacetic acid (EDTA), and dithiothreitol (DTT) were purchased from Sigma-Aldrich Corporation. Human recombinant PTP1B was purchased from Biomol Co. All other chemicals and solvents used were purchased from Sinopharm Chemical Reagent Co., Ltd., or Merck. 

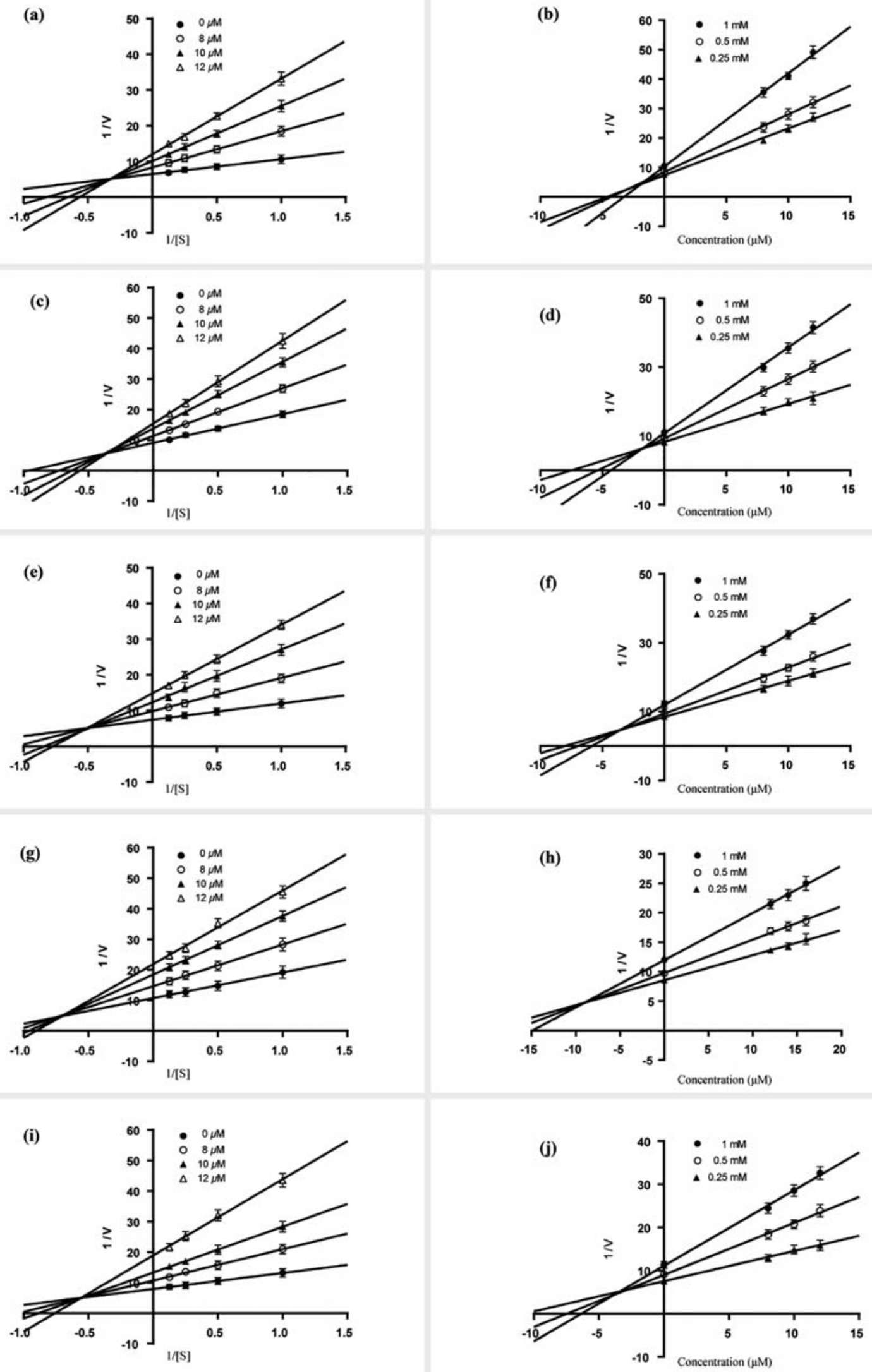

Fig. 5 Lineweaver-Burk plots for PTP1B inhibition of 1 (a), 2 (c) 3 (e), 8 (g), and 9 (i). Dixon plots for PTP1B inhibition of 1 (b), 2 (d) 3 (f), 8 (h), and 9 (j). 
- Table 4 Docking scores and interacting residues of compounds 1-3, 8, and 9 in PTP1B using LeDock.

\begin{tabular}{|c|c|c|c|}
\hline Compounds & $\begin{array}{l}\text { Binding energy } \\
\text { (kcal/mol) }\end{array}$ & $\mathrm{H}$-Bond interacting residues & Hydrophobic interacting residues \\
\hline Ligand Ca (catalytic inhibitor) & $-12.43^{b}$ & $\begin{array}{l}\text { Asp48, Trp179, Ser216, Ala217, Gly218, } \\
\text { Ile219, Gly220, Arg221, Gly259, Gln266 }\end{array}$ & $\begin{array}{l}\text { Tyr46, Val49, Ala217, lle219, Met258, Gln262, } \\
\text { Thr263 }\end{array}$ \\
\hline Ligand $A^{c}$ (allosteric inhibitor) & $-9.44^{d}$ & Asn193, Glu276 & $\begin{array}{l}\text { Ala189, Leu192, Phe196, Gly277, Lys279, Met282, } \\
\text { Phe280 }\end{array}$ \\
\hline \multirow[t]{2}{*}{1} & -5.84 & Gly183, Cys 215, Gly220, Arg221 & $\begin{array}{l}\text { Tyr46, Lys116, Trp179, Pro180, Asp181, Phe182, } \\
\text { Gln266 }\end{array}$ \\
\hline & -4.54 & $-\mathrm{e}$ & $\begin{array}{l}\text { Tyr152, Ala189, Ser190, Leu192, Asn193, Phe196, } \\
\text { Phe280 }\end{array}$ \\
\hline \multirow[t]{2}{*}{2} & -6.11 & $-\mathrm{e}$ & $\begin{array}{l}\text { Tyr20, Arg24, Tyr46, Asp48, Val49, Ala217, Ile219, } \\
\text { Gly220, Met258, Gly259, Gln262 }\end{array}$ \\
\hline & -5.96 & Lys197 & $\begin{array}{l}\text { Ala189, Leu192, Asn193, Phe196, Glu200, Gly277, } \\
\text { Phe280, lle281 }\end{array}$ \\
\hline \multirow[t]{2}{*}{3} & -5.45 & Ile219, Gly220, Thr263 & $\begin{array}{l}\text { Lys116, Trp179, Asp181, Gly183, Val184, Cys215, } \\
\text { Ser216, Ala217, Arg221, Asp265, Gln266 }\end{array}$ \\
\hline & -4.66 & $-\mathrm{e}$ & $\begin{array}{l}\text { Ala189, Leu192, Asn193, Phe196, Lys197, Glu200, } \\
\text { Gly277, Phe280, Ile281 }\end{array}$ \\
\hline \multirow[t]{2}{*}{8} & -5.56 & Trp179, Arg221 & $\begin{array}{l}\text { Tyr46, Asp48, Val49, Gly183, Cys215, Ser216, } \\
\text { Ala217, Gln262, Thr263, Gln266 }\end{array}$ \\
\hline & -5.14 & $-\mathrm{e}$ & $\begin{array}{l}\text { Ser187, Ala189, Leu192, Asn193, Phe196, Glu276, } \\
\text { Gly277, Phe280 }\end{array}$ \\
\hline \multirow[t]{2}{*}{9} & -5.56 & Trp179, Gly220 & $\begin{array}{l}\text { Gly183, Cys215, Ser216, Ala217, Ile219, Arg221, } \\
\text { Thr263, Gln266 }\end{array}$ \\
\hline & -5.21 & Lys197, Glu200 & Ala189, Leu192, Asn193, Phe196, Gly277, Phe280 \\
\hline
\end{tabular}

\section{Plant material}

The roots of $A$. styracifolius were collected from Dayuan forest farm of Yangshuo County, Guangxi Autonomous Region, China, in October 2012 and identified by Shihong Lv, an associate researcher of Guangxi Institute of Botany, Chinese Academy of Sciences. A voucher specimen (TCM, 2012-10-01) was deposited in the Herbarium of the Department of Pharmacognosy, Research Center of Natural Resources of Chinese Medicinal Materials and Ethnic Medicine, Jiangxi University of Traditional Chinese Medicine.

\section{Extraction and isolation}

The air-dried roots of $A$. styracifolius $(13.9 \mathrm{~kg})$ were macerated with $95 \%$ EtOH 3 times (10.0 L for each extraction) at room temperature. The filtrate was evaporated under reduced pressure to produce a residue $(1.3 \mathrm{~kg})$, which was suspended in $\mathrm{H}_{2} \mathrm{O}(1 \mathrm{~L})$ and then partitioned successively with petroleum ether $(3 \times 2 \mathrm{~L})$, $\mathrm{CHCl}_{3}(3 \times 2 \mathrm{~L})$, EtOAc $(3 \times 2 \mathrm{~L})$, and $n-\mathrm{BuOH}(3 \times 2 \mathrm{~L})$ to provide petroleum ether-soluble, $\mathrm{CHCl}_{3}$-soluble, EtOAc-soluble, and $\mathrm{n}$ $\mathrm{BuOH}$-soluble portions, respectively. The $\mathrm{CHCl}_{3}$-soluble portion $(118.9 \mathrm{~g})$ was fractionated by a HP-20 macroporous resin CC eluted with a gradient of EtOH- $\mathrm{H}_{2} \mathrm{O}(10 \times 45 \mathrm{~cm}, 1: 9,3: 7,1: 1$, $7: 3,95: 5, \mathrm{v} / \mathrm{v}$ ) to give 6 fractions (frs. H1-H6). Fr. H3 (6.6 g) was separated by CC over MCl CHP-20P resin eluted with $\mathrm{MeOH}-\mathrm{H}_{2} \mathrm{O}$ ( $75 \mu \mathrm{m}, 4 \times 45 \mathrm{~cm}, 3: 7,5: 5,7: 3,10: 0, v / v)$ to obtain 6 fractions
(Frs. H3M1-H3M6). Fr. H3M6 (2.7 g) was fractionated by CC on Sephadex $\mathrm{LH}-20(2 \times 200 \mathrm{~cm})$ eluted with $\mathrm{MeOH}$ to yield 5 fractions (frs. H3M6L1-H3M6L5). Fr. H3M6L3 (0.5 g) was separated by $\mathrm{CC}$ over silica gel eluted with $\mathrm{CHCl}_{3}-\mathrm{CH}_{3} \mathrm{COCH}_{3}$ (300 mesh, $3 \times 22 \mathrm{~cm}, 3: 1,1: 1,1: 3, \mathrm{v} / \mathrm{v}$ ) to obtain 5 fractions (Frs. H3M6L3S1-H3M6L3S5). Fr. H3M6L3S1 $(80.5 \mathrm{mg})$ was then repeatedly purified by PHPLC eluting with acetonitrile- $\mathrm{H}_{2} \mathrm{O}$ (ODS, $5 \mu \mathrm{m}, 2 \times 25 \mathrm{~cm}, 3: 7, \mathrm{v} / \mathrm{v})$ to obtain compounds $9\left(18.8 \mathrm{mg}, t_{\mathrm{R}}\right.$ $29 \mathrm{~min})$ and $6\left(5.8 \mathrm{mg}, t_{\mathrm{R}} 35 \mathrm{~min}\right)$. Fr. $\mathrm{H} 4(44.8 \mathrm{~g})$ was chromatographed by CC over ODS eluted by $\mathrm{MeOH}-\mathrm{H}_{2} \mathrm{O}(150 \mu \mathrm{m}$, $4 \times 22 \mathrm{~cm}, 6: 4,7: 3,8: 2,9: 1,10: 0, v / v)$ to give 15 fractions (Frs. H4O1-H4O15). Fr. $\mathrm{H} 4 \mathrm{O} 3$ (4.6 g) was separated by CC over $\mathrm{MCl}$ CHP-20P resin eluted with $\mathrm{MeOH}-\mathrm{H}_{2} \mathrm{O}(75 \mu \mathrm{m}, 4 \times 45 \mathrm{~cm}$, $6: 4,7: 3,8: 2,9: 1,10: 0, v / v)$ to obtain 5 fractions (Frs. H4O3M1-H4O3M5). Fr. H4O3M3 (1.8 g) was fractionated by CC on Sephadex $\mathrm{LH}-20(2 \times 200 \mathrm{~cm})$ eluted with $\mathrm{MeOH}$ to yield 6 fractions (Frs. H4O3M3L1-H4O3M3L6). Fr. H4O3M3L1 (173.4 mg) was then purified by PHPLC (ODS, $5 \mu \mathrm{m}, 2 \times 25 \mathrm{~cm}$ ) eluting with acetonitrile- $\mathrm{H}_{2} \mathrm{O}(5: 5, \mathrm{v} / \mathrm{v})$ to obtain compound $5\left(18.4 \mathrm{mg}, t_{R}\right.$ $25 \mathrm{~min})$ and $3\left(3.0 \mathrm{mg}, t_{R} 40 \mathrm{~min}\right)$. In a similar manner, $7(7.2 \mathrm{mg}$, $\left.t_{\mathrm{R}} 24 \mathrm{~min}\right), 8$ (10.2 mg, $\left.t_{\mathrm{R}} 31 \mathrm{~min}\right)$, and 1 ( $\left.40.3 \mathrm{mg}, t_{\mathrm{R}} 45 \mathrm{~min}\right)$ were obtained from Fr. H4O3M3L2, 2 (14.1 mg, $t_{R} 35 \mathrm{~min}$ ) from Fr. H4O3M3L5, and 4 (7.5 mg, $\left.t_{R} 37 \mathrm{~min}\right)$ from Fr. H4O3M3L6. 


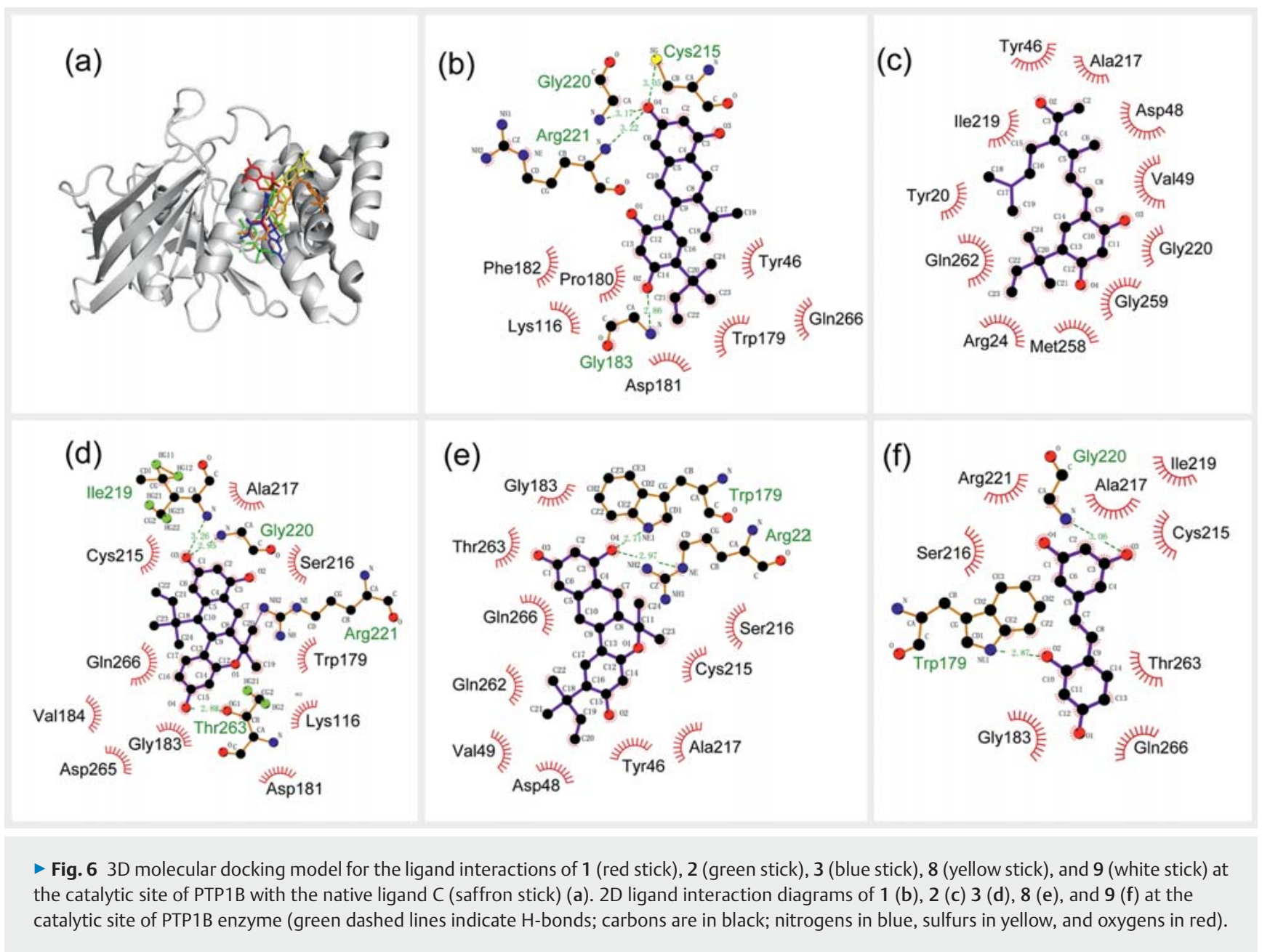

\section{PTP1B inhibitory activity assay}

The inhibitory activity of isolated compounds against PTP1B was tested in 96-well microplates by a previously described method [28]. In brief, to each well of a 96-well plate (final volume of $200 \mu \mathrm{L})$ were added $2 \mathrm{mM} p$-NPP and PTP1B $(0.1 \mu \mathrm{g})$ in a buffer containing $50 \mathrm{mM}$ citrate ( $\mathrm{pH} 6.0$ ), $0.1 \mathrm{M} \mathrm{NaCl}, 1 \mathrm{mM}$ EDTA, and $1 \mathrm{mM}$ DTT with or without test compounds. Following incubation at $37^{\circ} \mathrm{C}$ for $30 \mathrm{~min}$, the reaction was terminated by the addition of $1 \mathrm{M} \mathrm{NaOH}$. The absorbance of produced $p$-nitrophenol was measured at $405 \mathrm{~nm}$ with a photometer microplate reader (Multiskan Go 1510).

\section{Inhibition kinetic assay}

Two complementary kinetic methods, Lineweaver-Burk and Dixon plots $[22,29,30]$, were employed to determine the mode of PTP1B inhibition of the active stilbene derivatives (1-3, 8, and 9). In the Lineweaver-Burk plot method, enzymatic reactions were determined at various concentrations of $p$-NPP substrate $(0.125$, $0.25,0.5$, and $1 \mathrm{mM}$ ) with active compounds at different concentrations $(0,8,10$, and $12 \mu \mathrm{M})$. To obtain a Dixon plot, enzymatic reactions at various concentrations of active compound $(0,8,10$, and $12 \mu \mathrm{M}$ ) were evaluated by monitoring the effects of different concentrations of the substrate $(0.25,0.5$, and $1 \mathrm{mM})$. The inhibi- tion constants $\left(K_{i}\right)$ were determined by the interpretation of Dixon plots, where the value of the $x$-axis was taken as the value of $K_{i}$.

\section{Molecular docking analysis}

The crystal structures of PTP1B, with a catalytic inhibitor 3-(\{5[(N-acetyl-3-\{4-[(carboxycarbonyl)(2-carboxyphenyl)amino]-1naphthyl\}-L-alanyl)amino]pentyl\}oxy)-2-naphthoic acid (ligand C, PDB ID: 1NNY), and a allosteric inhibitor 3-(3,5-dibromo-4-hydroxy-benzoyl)-2-ethyl-benzofuran-6-sulfonic acid (4-sulfamoylphenyl)-amide (ligand A, PDB ID: 1T49) were obtained from the RCSB Protein Data Bank website [25]. The native inhibitors and water molecules were removed from the structures before docking simulation using LeDock. The ligand structures were drawn using ChemDraw 2D software (version 15.0). Then they were converted to $3 \mathrm{D}$ structures using the same ChemDraw 3D software in which they were subjected to energy minimization using the MM2 menu and saved as files in mol2 format. Docking simulation was performed using LeDock to assess the appropriate binding orientations and conformations of the ligand molecules. For 1 NNY, the binding box of ligands was defined as a grid box centered on coordinates $X=29.242, Y=28.319, Z=20.318$, with a size of $13.5 \AA \times 9.5 \AA \times 10.0 \AA$. For 1 T49, the binding box of ligands was defined as a grid box centered on coordinates 


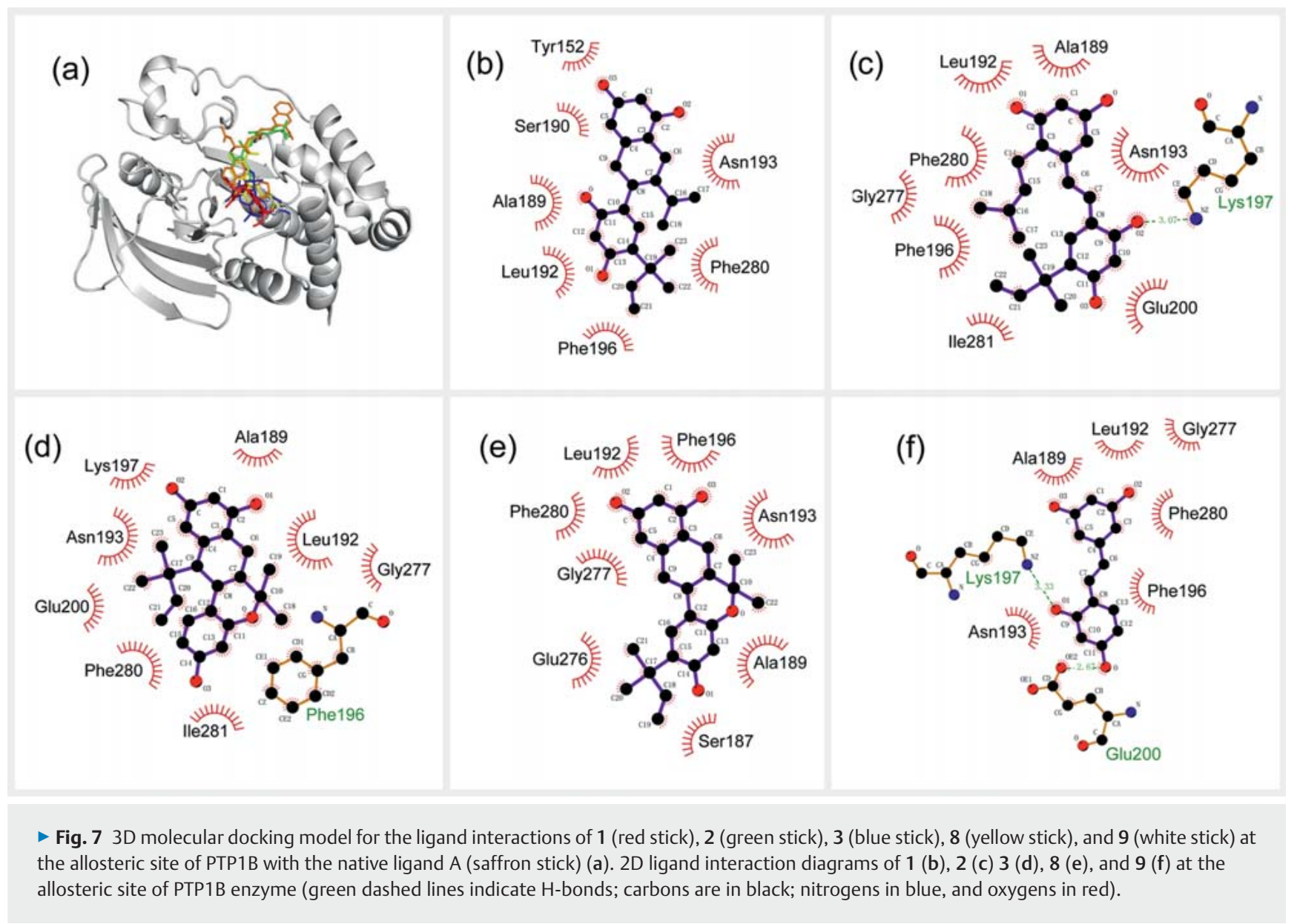

$X=55.319, Y=31.520, Z=22.447$, with a size of $12 \AA \times 10 \AA x$ $10 \AA$. The root-mean-square deviation (RMSD) value is set to $0.5 \AA$, and remaining parameters were set by default. The docking protocol was validated by the RMSD value that was measured by re-docking of native inhibitor into the corresponding crystal structure. The RMSD values for re-docking complexes of ligand $C$ with $1 \mathrm{NNY}$ and ligand $A$ with $1 \mathrm{~T} 49$ were recorded as 1.360 and $0.281 \AA$, respectively, indicating that this docking workflow reproduced the experimental binding mode. The docking calculation results were analyzed using PyMOL (version 1.7.0), while the hydrogen bond interacting residues and hydrophobic interacting residues were visualized using PLIP and LigPlot+ (version 4.5.3).

\section{Statistical analysis}

All results are expressed as the mean with $95 \% \mathrm{Cl}$ based on triplicate experiments and evaluated using GraphPad Prism 6 (version 6.01).

Compound 1. Yellow amorphous powder; $[\alpha]_{D}^{25} 0$ (c 0.30 , $\mathrm{MeOH}) ; \mathrm{UV}(\mathrm{MeOH}) \lambda_{\max }(\log \varepsilon): 211$ (4.34), 229 sh (4.14), 285 (3.75) nm; IR (KBr) $v_{\max }: 3442,2964,2930,1621,1501,1235$, $1140,1030,889$, and $838 \mathrm{~cm}^{-1} ;{ }^{1} \mathrm{H}$ and ${ }^{13} \mathrm{C}$ NMR data (600 and $150 \mathrm{MHz}$, acetone- $d_{6}$ ): see $\boldsymbol{>}$ Tables 1 and 2 ; HRESIMS (negative ion mode) $\mathrm{m} / \mathrm{z}$ : $379.1906\left([\mathrm{M}-\mathrm{H}]^{-}\right.$, calcd for $\mathrm{C}_{24} \mathrm{H}_{27} \mathrm{O}_{4}$ 379.1915).
Compound 2. Yellow amorphous powder; $\mathrm{UV}(\mathrm{MeOH}) \lambda_{\max }$ (log ع): 208 (4.29), 229 sh (3.84), 287 (3.48), and 320 (3.26) nm; IR (KBr) $v_{\text {max }}: 3424,2969,2928,1607,1384,1276,1136,922$, and $838 \mathrm{~cm}^{-1} ;{ }^{1} \mathrm{H}$ and ${ }^{13} \mathrm{C}$ NMR data (600 and $150 \mathrm{MHz}$, methanol- $d_{4}$ ): see $>$ Tables 1 and 2; HRESIMS (negative ion mode) $\mathrm{m} / \mathrm{z}$ : $379.1933\left([\mathrm{M}-\mathrm{H}]^{-}\right.$, calcd for $\left.\mathrm{C}_{24} \mathrm{H}_{27} \mathrm{O}_{4} 379.1915\right)$.

Compound 3. Yellow amorphous powder; $[\alpha]_{D}^{25} 0$ (c 0.22 , $\mathrm{MeOH}) ; \mathrm{UV}(\mathrm{MeOH}) \lambda_{\max }$ (log $\left.\varepsilon\right): 209$ (4.36), 229 sh (4.11), and 285 (3.67) nm; IR (KBr) $v_{\max }: 3269,2972,2929,1618,1506$, $1462,1385,1308,1173,1123,999$, and $846 \mathrm{~cm}^{-1} ;{ }^{1} \mathrm{H}$ and ${ }^{13} \mathrm{C}$ NMR data (600 and $150 \mathrm{MHz}$, methanol- $d_{4}$ ): see $>$ Tables 1 and 2; HRESIMS (negative ion mode) m/z: $379.1907\left([\mathrm{M}-\mathrm{H}]^{-}\right.$, calcd for $\left.\mathrm{C}_{24} \mathrm{H}_{27} \mathrm{O}_{4} 379.1915\right)$.

Compound 4. Yellow amorphous powder; $[\alpha]_{D}^{25} 0$ (c 0.45 , $\mathrm{MeOH}) ; \mathrm{UV}(\mathrm{MeOH}): \lambda_{\max }(\log \varepsilon): 209$ (4.18), 229 sh (3.65), and 284 (3.32) nm; IR (KBr) $v_{\max }: 3341,2971,2930,1622,1491$, $1371,1298,1137,1021,918$, and $836 \mathrm{~cm}^{-1} ;{ }^{1} \mathrm{H}$ and ${ }^{13} \mathrm{C}$ NMR data ( 600 and $150 \mathrm{MHz}$, methanol- $d_{4}$ ): see $>$ Tables 1 and 2; HRESIMS (negative ion mode) $\mathrm{m} / \mathrm{z}$ : $447.2526\left([\mathrm{M}-\mathrm{H}]^{-}\right.$, calcd for $\mathrm{C}_{29} \mathrm{H}_{35} \mathrm{O}_{4}$ 447.2541).

Compound 7. Yellow amorphous powder; $[\alpha]_{D}^{25} 0$ (c 0.12 , $\mathrm{MeOH}) ; \mathrm{UV}(\mathrm{MeOH}) \lambda_{\max }(\log \varepsilon): 229$ sh (3.48) and 287 (3.11) $\mathrm{nm}$; IR (KBr): $v_{\max } 3442,2970,2933,1660,1613,1494,1347$, 1133, 1064, 1019, 938, and $854 \mathrm{~cm}^{-1} ;{ }^{1} \mathrm{H}$ and ${ }^{13} \mathrm{C}$ NMR data $(600$ and $150 \mathrm{MHz}$, methanol- $d_{4}$ ): see $>$ Tables 1 and $\mathbf{2}$; HRESIMS (pos- 
itive ion mode): $395.1855\left([\mathrm{M}+\mathrm{H}]^{+}\right.$, calcd for $\mathrm{C}_{24} \mathrm{H}_{27} \mathrm{O}_{5}$ 395.1853).

\section{Supporting Information}

The spectra (1D and 2D NMR, UV, IR, and HRESIMS) of the new compounds 1 (Fig. 1S-15S), 2 (Fig. 16S-24S), 3 (Fig. 25S-34S), 4 (Fig. 35S-47S), and 7 (Fig. 48S-58S) are available as Supporting Information.

\section{Acknowledgements}

This work was financially supported by National Natural Science Foundation of China (No. 81160509, 81360475), Young Scientist Development Program of Jiangxi Province (No. 20142BCB23024), Jiangxi Provincial Natural Science Fund Project (No. 20151BAB205074), and The Scientific Foundation of Double World-classes Subject Development of Jiangxi University of Traditional Chinese Medicine (No. JXSYLXKZHYAO027). We thank Shi-Hong Lv and Yan Liu from Guangxi Institute of Botany, Chinese Academy of Sciences for assistance during the collection of A. styracifolius root material.

Conflict of Interest

The authors declare that they have no conflict of interest.

References

[1] Centers for Disease Control and Prevention (CDC). National Diabetes Statistics Report; 2017. Available at https://www.cdc.gov/diabetes/ pdfs/data/statistics/national-diabetes-statistics-report.pdf. Accessed March 6, 2018

[2] World Health Organization (WHO). Diabetes Fact Sheet 312. Available at https://web.archive.org/web/20130826174444/http://www.who.int/ mediacentre/factsheets/fs312/en/. Accessed August 26, 2013

[3] Cheng A, Dubé N, Gu F, Tremblay ML. Coordinated action of protein tyrosine phosphatases in insulin signal transduction. Eur J Biochem 2002; 269: 1050-1059

[4] Kenner KA, Anyanwu E, Olefsky JM, Kusari J. Protein-tyrosine phosphatase $1 \mathrm{~B}$ is a negative regulator of insulin- and insulin-like growth factorI-stimulated signaling. J Biol Chem 1996; 271: 19810-19816

[5] Comeau AB, Critton DA, Paqe R, Seto CT. A focused library of protein tyrosine phosphatase inhibitors. J Med Chem 2010; 53: 6768-6772

[6] Kasibhatla B, Wos J, Peters KG. Targeting protein tyrosine phosphatase to enhance insulin action for the potential treatment of diabetes. Curr Opin Investig Drugs 2007; 8: 805-813

[7] Qian S, Zhang M, He Y, Wang W, Liu S. Recent advances in the development of protein tyrosine phosphatase $1 \mathrm{~B}$ inhibitors for type 2 diabetes. Future Med Chem 2016; 8: 1239-1258

[8] Eleftheriou P, Geronikaki A, Petrou A. PTP1B inhibition, a promising approach for the treatment of diabetes type II. Curr Top Med Chem 2019; 19: $246-263$

[9] Jagtap UB, Bapat VA. Artocarpus: a review of its traditional uses, phytochemistry and pharmacology. J Ethnopharmacol 2010; 129: 142-166

[10] Zhang PZ, Gu J, Zhang GL. Novel stilbenes from Artocarpus nanchuanensis. J Asian Nat Prod Res 2015; 17: 217-223

[11] Zhang XS, Wu ZY. Zhongguo Zhiwu Zhi (Flora of China). Beijing: Science Press; 1998: 40-55
[12] Jia MR, Zhang Y. Dictionary of Chinese ethnic Medicine. Beijing: China Medical Science and Technology Press; 2016: 85-86

[13] Ren G, Yi WF, Zhong GY, Yuan W], Peng JB, Ma ZL, Zeng JX. Artostyracins $\mathrm{A}-\mathrm{C}$, three new isoprenylated 2-arylbenzofurans from Artocarpus styracifolius. Phytochem Lett 2014; 10: 235-239

[14] Ren G, Xiang HY, Hu ZC, Liu RH, Zhou ZW, Huang HL, Shao F, Yang M. A new isoprenylated flavone from the root bark of Artocarpus styracifolius. Biochem Syst Ecol 2013; 46: 97-100

[15] Ren G, Xiang HY, Hu ZC, Liu RH, Yi WF, Peng JB, Yuan JB. Inhibitory effects of phenolic compounds from Artocarpus styracifolius on respiratory burst of rat neutrophils. Pharm Biol 2014; 52: 944-950

[16] Bourjot M, Apel C, Martin MT, Grellier P, Nguyen VH, Gueritte F, Litaudon M. Antiplasmodial, antitrypanosomal, and cytotoxic activities of prenylated flavonoids isolated from the stem bark of Artocarpus styracifolius. Planta Med 2010; 76: 1600-1604

[17] Yu MH, Zhao T, Yan GR, Yang HX, Wang HY, Hou AJ. New isoprenylated flavones and stilbene derivative from Artocarpus hypargyreus. Chem Biodivers 2012; 9: 394-402

[18] Fu DX, Chen L, Hou AJ, Yao Q, Zhang WY. Chemical constituents of Morus nigra. Chin Tradit Herbal Drugs 2005; 36: 1296-1299

[19] Lin CN, Lu CM, Huang PL. Flavonoids from Artocarpus heterophyllus. Phytochemistry 1995; 39: 1447-1451

[20] Baderschneider B, Winterhalter P. Isolation and characterization of nove stilbene derivatives from Riesling wine. J Agric Food Chem 2000; 48 2681-2686

[21] Huang YL, Tsai W], Shen CC, Chen CC. Resveratrol derivatives from the roots of Vitis thunbergii. J Nat Prod 2005; 68: 217-220

[22] Lineweaver $\mathrm{H}$, Burk $\mathrm{D}$. The determination of enzyme dissociation constants. J Am Chem Soc 1934; 56: 658-666

[23] Ha MT, Seong SH, Nguyen TD, Cho WK, Ah KJ, Ma JY, Woo MH, Choi JS, Min BS. Chalcone derivatives from the root bark of Morus alba L. act as inhibitors of PTP1B and $\alpha$-glucosidase. Phytochemistry 2018; 155: 114125

[24] Ha MT, Park DH, Shrestha S, Kim M, Kim JA, Woo MH, Choi JS, Min BS. PTP1B inhibitory activity and molecular docking analysis of stilbene derivatives from the rhizomes of Rheum undulatum L. Fitoterapia 2018; 131: $119-126$

[25] Wiesmann C, Barr KJ, Kung J, Zhu J, Erlanson DA, Shen W, Fahr B], Zhong M, Taylor L, Randal M, McDowell RS, Hansen SK. Allosteric inhibition of protein tyrosine phosphatase 1B. Nat Struct Mol Biol 2004; 11: 730-737

[26] Du Y, Ling C, Zhang M, Shen J, Li Q. Discovery of novel, potent, selective and cellular active ADC type PTP1B inhibitors via fragment-docking-oriented de novel design. Bioorg Med Chem 2015; 23: 4891-4898

[27] Liu G, Xin Z, Liang H, Abad-Zapatero C, Hajduk PJ, Janowick DA Szcepankiewicz BG, Pei Z, Hutchins CW, Ballaron SJ, Stashko MA, Lubben TH, Berg CE, Rondinone CM, Trevillyan JM, Jirousek MR. Selective protein tyrosine phosphatase 1B inhibitors: targeting the second phosphotyrosine binding site with non-carboxylic acid-containing ligands. J Med Chem 2003: 46: 3437-3440

[28] Cui L, Na M, Oh H, Bae EY, Jeong DG, Ryu SE, Kim S, Kim BY, Oh WK, Ahn JS. Protein tyrosine phosphatase 1B inhibitors from Morus root bark. Bioorg Med Chem Lett 2006; 16: 1426-1429

[29] Dixon M. The determination of enzyme inhibitor constants. Biochem 1953; 55: 170-171

[30] Cornish-Bowden A. A simple graphical method for determining the inhibition constants of mixed, uncompetitive and non-competitive inhibitors. Biochem J 1974; 137: 143-144 